\title{
Entrevista com Lídia Jorge
}

\section{Conduzida por Nazaré Torrão}

CEL - Centre d'Études Lusophones

Faculté des lettres - Unité de portugais

Université de Genève

•nazare.torrao@unige.ch

DOI https://doi.org/10.34913/

journals/lingua-lugar.2020.e214 


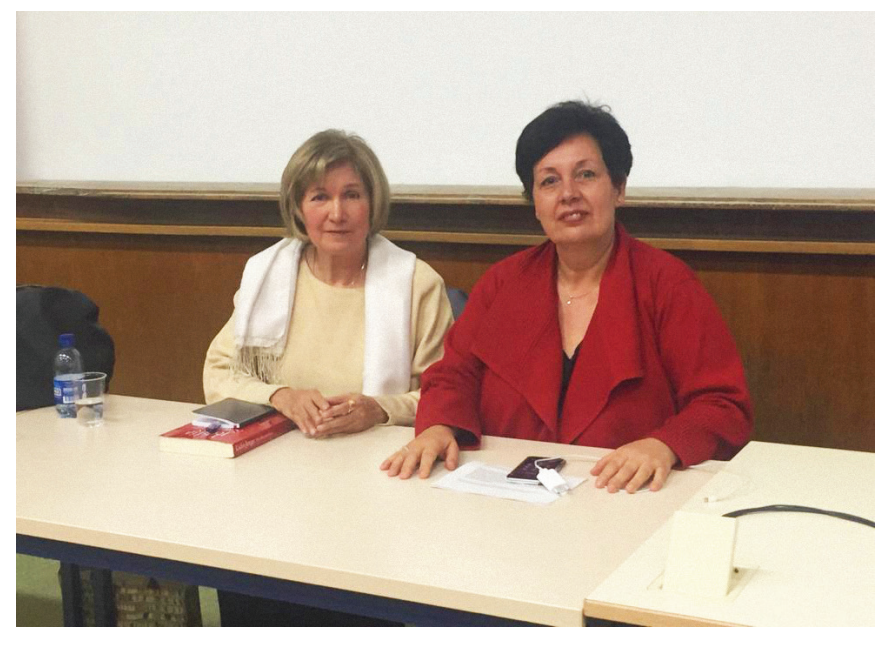

A conversa com Lídia Jorge inaugura uma série de entrevistas da secção com o mesmo nome da revista Língua-lugar. Palavra puxa palavra e, na troca de ideias, apercebemo-nos de como as conversas com os autores podem revelar a interligação importantíssima das três linhas que guiam a revista: literatura, história e cultura. Particularmente na obra de uma escritora que se reclama da tradição literária portuguesa, cujas vivências pessoais foram (como as de todos nós) determinadas pelo tempo em que viveu e o lugar que a viu nascer, e que afirma claramente a importância do movimento pendular entre a cultura e a história que enformam as suas obras e a função formativa e informativa que deseja que as mesmas desempenhem na sociedade, através de uma experiência estética.

Esta entrevista a Lídia Jorge, orientada por Nazaré Torrão, docente da Unité de portugais da Faculté des lettres da Université de Genève,foi realizada a 2 de maio de 2019, na mesma faculdade, em dois contextos particulares: uma aula de literatura com um grupo de jovens que tinham estudado nesse semestre o romance Os Memoráveis, e um encontro com um grupo mais alargado, composto por estudantes universitários, jovens de turmas do Ensino de Português no Estrangeiro (EPE), professores do EPE e público genebrino que não seria particularmente conhecedor da realidade portuguesa. Esses dois encontros foram reunidos numa só entrevista. 
170 Nazaré Torrão - Lídia Jorge nasceu no Algarve, em Boliqueime, e pertence à geração de autores que começou a publicar depois do 25 de Abril de 1974. O seu primeiro romance, O Dia dos Prodígios, alcançou enorme sucesso, tanto entre a crítica especializada como entre o público, que continua a crescer até hoje. Atualmente a sua obra conta com 12 romances, 2 peças de teatro, 4 coletâneas de contos, 3 títulos de literatura infantil [e um volume de poesia e outros de crónicas, publicados depois de a entrevista ter tido lugar]. Os textos de Lídia Jorge cativam pela capacidade para criar atmosferas e universos fictícios para os quais o leitor é transportado pela sensualidade da sua escrita, pela complexidade das personagens criadas e pelos temas abordados. Apesar das particularidades de cada uma dessas obras, e das singularidades da sociedade portuguesa em que estão inseridos, os seus tópicos assumem uma abrangência universal, uma vez que a autora desenvolve questões amplas como sejam as ruturas familiares, o peso da separação, o enigma do amor, a condição feminina, o poder das revoluções, ou de forma mais geral, a evolução das sociedades que sempre deixam de lado aqueles que não conseguem acompanhar o ritmo da mudança. É costume assinalar que atravessa a sua obra uma sensibilidade ética, e em face do futuro, uma visão profética. Assim, para passar a palavra a Lídia Jorge, eu perguntar-Ihe-ia de que forma é que a sua vida influenciou esta capacidade de tratar os problemas humanos.

Lídia Jorge - Muito obrigada, professora Nazaré. Agradeço do mesmo modo a todos os presentes, pelo que vejo, um público muito heterogéneo, com forte presença dos mais jovens. É sobretudo aos mais jovens que eu gostaria de me dirigir de forma muito particular. Os estudantes mais velhos, e os adultos que aqui estão presentes, são por certo pessoas já cativadas para a literatura. Mas quando percebo que se encontram neste auditório alunos de treze, catorze anos, receio que o meu discurso, em vez de os atrair para a grande disciplina da Leitura, e da Literatura, os afaste. Receio não encontrar a estratégia certa para lhes demonstrar que este é um campo fantástico de liberdade, de invenção, de capacidade de criar outros mundos, de treino para estarmos connosco próprios e entendermos os outros, como nenhuma outra arte o pode fazer. Mas a pergunta é direta e eu não vou fugir a ela - Que percurso fiz para chegar a este campo, o da Literatura? Sinceramente, vos digo, e talvez seja desconcertante o que digo - enveredei pelo mundo dos livros porque na altura não havia televisão. 
LJ - Trata-se de uma questão de tempo. Quando eu era pequena não havia televisão. Fui criança numa casa de campo, no meio de um bosque, no sul de Portugal, isolada, tendo por companhia animais domésticos e livros. Os livros atravessaram o meu caminho. Mas, se fosse hoje, eu passaria porventura as tardes inteiras a ver televisão, e em vez de desejar escrever livros, sonharia ser modelo ou cantora, como todas as crianças agora querem ser, ainda que eu não tivesse capacidade para cantar nem físico para caminhar a galope nas passarelas. Ou pelo menos desejaria ser detentora de alguma habilidade extraordinária para poder participar nos concursos da noite. Esses são os modelos que estão a ser apresentados às crianças de famílias não afortunadas culturalmente. Inebriada por essas luzes, talvez não me tivesse interessado pela leitura, muito menos pela escrita, esse jogo calado, longe das luzes de todas as ribaltas. Mas a verdade é que me aconteceu ter nascido um ano depois do fim da Segunda Guerra Mundial, e nessa altura os livros eram o único meio que uma criança como eu tinha de aceder ao mudo amplo da memória, da imaginação e da fantasia. Os livros vieram ter comigo.

\section{NT - Diz que os livros vieram ter consigo?}

LJ - Sim, na casa dos meus avós maternos onde vivia, chegou às minhas mãos uma pequena biblioteca. Uma biblioteca de origem ainda hoje um tanto misteriosa. O meu bisavô materno foi quem a formou, e esse homem constitui um enigma na nossa família. Um homem pobre que era carpinteiro nas horas vagas e agricultor a tempo inteiro. No entanto, esse camponês carpinteiro era um homem culto. Comprava os livros correntes na época, escritores românticos como os romances de Camilo Castelo Branco, de Júlio Dinis, Silva Gaio, e comprava traduções, sobretudo de livros franceses. Além de Literatura e de História, adquiriu livros práticos na área da Agricultura, Astronomia e Zoologia. Esse meu bisavô veio a falecer muito novo, ainda no início do século XX. Quando isso aconteceu, a sua mulher ficou desesperada. Tinham muitos filhos, como acontecia então, e como os livros desse meu bisavô significavam dinheiro de comida que não trazia para casa, a minha bisavó, alguns dias depois de o marido falecer, fez uma fogueira em frente da casa para queimá-los. Uma das suas filhas, muito jovem, tinha aprendido a ler e a escrever com o seu pai, então ela, quando viu que os livros iam ser queimados, retirou os que pôde da fogueira e guardou-os. Muitos anos depois, quando eu ainda era pequena, esses livros foram-me dados como os livros da família salvos do fogo. Lembro-me de pegar neles com devoção, mesmo sem 
perceber muito bem o que lá estava escrito. Exerciam sobre mim um fascínio extraordinário. Alguém na família tinha sido um grande leitor. Aqueles livros não tinham só umas histórias lá dentro, tinham também a voz desse meu bisavô de quem só sobejou uma fotografia, um homem seco como os portugueses o eram, de estatura pequena, muito moreno, com grande bigode, um homem parecido com os afegãos pobres, os que andam de burro por aquelas montanhas nuas. O meu bisavô era assim. Na fotografia usava um lenço ao pescoço. Nós julgamos que seria carbonário, que pertenceria a um grupo de revolucionários da altura. Pertenceria a um grupo político de base que lutava contra o analfabetismo e contra uma sociedade não democrática. Este meu bisavô longínquo é um dos suportes da minha vida. Comecei a escrever muito cedo, pequenas histórias para não estar sozinha, e esse ainda é o sentimento que mantenho, escrevo para provocar a voz da outra pessoa, para provocar o retorno, uma resposta em voz alta que me faça companhia.

\section{NT - Isso foi o início, mas depois houve por certo outras situações que determinaram o seu percurso.}

LJ - Há sempre uma parte que não se explica, que é sem porquê. Mas, sem dúvida, que a mudança acelerada destas décadas tem sido um elemento determinante. Sentei-me num balcão que dá para o meu próprio país, mas a partir dele tenho observado o mundo e ao mesmo tempo a vida inteira. Sinto-me testemunha do tempo que passa. Conheci a ditadura, a pobreza, o analfabetismo, a falta de liberdade, e conheci o desejo de mudança de um povo inteiro. Fui testemunha dos movimentos que pugnavam pela mudança, pessoas que desejavam libertar o país da ditadura. Pessoas que participavam na guerra de África e que a consideravam um conflito delapidador e injusto, contra o sentido da História. Contra esse tremendo desajuste, entretanto, aconteceu a revolução. Então conheci um país que desejou que os países africanos e orientais fossem definitivamente livres. Conheci um país que quis pertencer à União Europeia, um país que conseguiu ultrapassar o atraso económico e o analfabetismo. Hoje em dia, temos avós analfabetos que convivem com netos doutorados e alguns estão a ensinar em importantes universidades um pouco por toda a parte. Foi uma alteração honrosa. Por outro lado, nesta mudança salutar em direção à modernidade, sobejaram resquícios arcaicos que não foram erradicados, e isso cria conflitos sociais e familiares, situações de desigualdade. É também um país que foi eminentemente rural e, como toda a gente sabe, os países rurais são muito diferentes dos países cujo tecido urbano é forte. Na cidade, acreditamos que o mal é resolvido pelo sistema - se somos pobres 
o sistema tem de nos ajudar - mas quem tem uma visão rural, e sobretudo rural antiga, tem a ideia de que só a natureza pode salvar a pessoa, ou só Deus pode ministrar a justiça. Ora a escrita entra pelos ângulos da vida humana banal, mas alimenta a ambição de atingir pela palavra os sentidos primeiros e finais da vida a que aludia a Professora Nazaré Torrão.

NT - Podemos, pois, concluir que o 25 de Abril foi um fator determinante de mudança e perpassa vários dos seus livros. Para o primeiro, O Dia dos Prodígios, é determinante. Também em Os Memoráveis esse é o tema central, e foi escrito, já o tem dito, a pensar nos jovens. Temos aqui tantos, vamos começar por falar desse livro.

LJ - A revolução portuguesa foi ontem. A nível interpretativo, está tudo em aberto. Passaram-se 45 anos após o 25 de Abril, e nada está fechado. Ao longo deste tempo, sempre se tem levantado a questão - Foi uma revolução ou tratou-se apenas de um golpe de estado? As interpretações têm sido diferentes. Houve quem dissesse - "Não, não foi uma revolução porque não se mudaram as estruturas profundas". Outros, pelo contrário, têm dito - "Sim, foi uma revolução porque houve alto risco de vida por parte dos seus intérpretes, porque a ação se saldou pela deposição de um regime, porque se assistiu à substituição dos rostos que conduziram o país, e houve, sobretudo, o mais fundamental, a adesão massiva do povo ao movimento transformador". Hoje, à distância, deve-se acrescentar, sobretudo, um facto - foi uma revolução muito especial porque foi uma revolução pacífica. Apesar do alto risco, não houve efusão de sangue e isso marcou a linha deslizante que se verificou a seguir à mesma.

NT - Considera então que o carácter pacífico da Revolução dos Cravos explica a fraca mudança a que se assistiu nas estruturas profundas da sociedade portuguesa? É isso que quer dizer com Os Memoráveis?

LJ - Vejamos, há uma alteração do regime, mas, ao mesmo tempo, houve uma parte dessa revolução que não subverteu as bases tradicionais, a sociedade não sofreu um golpe violento nas estruturas, e esse facto fez com que, em vários setores da realidade social, se tivesse prolongado uma certa inércia e atraso no nosso país. Instauraram-se as bases democráticas para uma sociedade moderna, mas ao mesmo tempo a alteração não foi tão funda que tivesse permitido uma mudança substancial da cultura em Portugal. O país cresceu, mas do ponto de vista cultural Portugal manteve muitos traços próprios da sua estrutura arcaica. Ainda hoje, Portugal continua a ser um país pouco reativo, um país amedrontado, com dificuldade em emitir opinião, além de ainda 
apresentar largas zonas de pobreza. Esses aspetos permitiram que a certa altura, em meados dos anos noventa, se pudesse dizer que a Revolução não havia sido uma revolução - "O 25 de Abril não foi uma revolução, tirem o R. Foi apenas uma evolução".

\section{NT - Mas essa não é a sua perspetiva.}

LJ - Não, não é. Ao longo de todos estes anos, mantive a ideia de que o dia 25 de Abril fora o momento mais importante não só da nossa vida coletiva, como na própria esfera privada, fora um dos dias mais importantes da minha própria vida. Encontrava-me em África na altura, e portanto vivi à distância o que se passava em Lisboa, mas de uma maneira muito intensa, porque sabia que, ao libertar-se o nosso país, libertavam-se ao mesmo tempo os países africanos para serem autónomos e independentes e isso, para mim, era muito importante. Era como eu via a História recente. Porém, nunca tinha pensado escrever um livro como Os Memoráveis. Só que, por volta de 2011, abateu-se a grande crise sobre Portugal e os portugueses ficaram em estado muito crítico. A Europa não nos abandonou completamente, mas desprezou-nos, a nós e à Grécia, de forma muito visível. Os portugueses enquanto cidadãos transportam consigo um complexo de culpa muito forte, como se ainda se sentissem torturados pela Inquisição. Em tempos mais próximos, foram limitados pelas baias do Estado Novo. Quando a crise financeira chegou, ficaram mudos, não reagiram. Quando o fizeram manifestaram-se com flores, pacificamente, criando imagens que correram o mundo como, por exemplo, a imagem de uma jovem mulher a oferecer cravos aos polícias, no decurso de uma manifestação, em Lisboa, no Outono de 2012.

\section{NT - Uma rapariga a abraçar o polícia...}

LJ - Sim, a abraçar um dos polícias que guardavam as instalações da delegação do FMI, diante das quais uma multidão gigantesca protestava. Creio ter sido o La Vanguardia que titulava que em Portugal se protestava com flores e se reivindicava com cânticos. O que é belo, sem dúvida, mas, por outro lado, é esse mesmo temperamento que explica que os jovens nos anos de Troika emigrassem submissos, tal como os seus avós, emigrantes económicos, o haviam feito, e tal como eles, sem dizerem uma palavra de revolta ou protesto, antes culpabilizados, diminuídos, como se o seu país não valesse nada. Partiam, sobretudo com a ideia de que a crise financeira, que se abatera sobre o país, era fruto do regime democrático, e tinha tido origem nos desmandos da geração que havia feito a revolução. Muitos começaram a elogiar o regime da ditadura. 
Pensando nesse equívoco, comecei a escrever esse livro. Escrevi-o para eles, os jovens que se submeteram sem falar, sem dizerem absolutamente nada. Quis lembrar-Ihes que o país dos seus pais e avós tinha passado por um percurso honroso que valia a pena lembrar, bem como os meandros da História que sempre se desenrola num plano cínico. E ao mesmo tempo para lhes dizer que mantivessem a esperança - quando uma situação se torna insuportável alguns têm de dar a vida, se necessário, para que haja uma mudança.

\section{NT - Está a falar de uma utopia?}

LJ - Sim, estou. Claro que esta é uma atitude utópica e idealista, mas a literatura, entre outras, tem essa tarefa a seu cargo. A literatura pode transfigurar, pode, através da palavra e da busca da beleza, dizer sem usar as palavras exatas - "Não se acomodem". Escrevi Os Memoráveis por isso. Por uma memória longa, de um dia maravilhoso, que libertou gerações, que evitou a morte de muitos jovens em África, de um lado e de outro. Para mostrar aos jovens como a memória do passado pode ser construtora de uma subjetividade rica, capaz de compreender o significado do que é a memória do futuro. Desejo que pensem alguma coisa contrária ao que escreveu Ortega y Gasset - "Nas revoluções, a abstração tenta sublevar-se contra o real: por isso o fracasso é consubstancial às revoluções". Sabe-se disso, sabe-se que a utopia tem um lado de puro ideal que não suporta a realidade, mas também se sabe que as revoluções acontecem quando a realidade se torna insuportável e Ortega y Gasset esqueceu-se de acrescentar essa nota. Ora em Portugal a revolução aconteceu porque a realidade tinha-se tornado insuportável.

Público - Neste seu livro é abordado não só o aspeto maravilhoso da revolução, mas também aquele lado que foi esquecido, e que também fez parte dela. Para a nossa geração é importante ter um conhecimento completo de ambos os lados. Ficou-nos só essa fábula fantástica, e quem viveu ou recorda tem tendência a esquecer uma outra memória, a das pessoas que estavam contra a revolução, a das vozes que não foram ouvidas. Por que é que achou pertinente, quarenta anos depois, fazer ouvir essas vozes outra vez?

LJ - Quis mostrar que ao reviver-se uma realidade, convém não a simplificar, por isso neste caso o relato assume a forma de uma fábula. Uma coisa é a verdade histórica, que também é uma ficção, embora os factos evocados sejam do domínio do que se concebe como real, e pertencente à esfera pública, sendo a ficção, sobretudo, do domínio do privado 
e a sua realidade inscreve-se no plano da transfiguração. Por isso a História tende a simplificar, a alinhar os nomes dos que estiveram na primeira linha, os intérpretes oficiais, aqueles que em primeira mão enchem os títulos dos jornais. A História tende a suprimir os dados que considera irrelevantes para o sucesso narrativo, socorrendo-se de datas, nomes, rasurando a inutilidade do quotidiano e a complexidade de cada figura. Quando, hoje em dia, os jovens veem os nomes daqueles que fizeram a revolução, cristalizados, imóveis, nos papéis que no fio da linha dos atos públicos desempenharam, não mergulham na história pessoal de cada um deles. Eu pretendi reinventar as suas vidas de modo a mostrar que estes homens não tinham sido propriamente heróis, apenas memoráveis. Há uma grande diferença: o herói é aquele que é irréprochable, não merece repreensão, o herói grego, aquele que não tem defeito. E o memorável, é apenas aquele que merece ser lembrado por ter interpretado atos decisivos, embora muitas vezes contraditórios. O memorável é aquele que deve ser reconhecido pelo bem e pelo mal que injetou na História. O memorável é literário porque não é unívoco, é um ser complexo.

\section{Público - Nessa linha de ideias, o herói seria um ser simplificado?}

LJ - Creio que sim. Ao contrário dos heróis, os memoráveis servem para mostrar que qualquer decisão na vida pública passa por atos individuais de escolha e que, por vezes, quem escolhe está completamente isolado e joga cegamente toda a sua vida numa ação. Quando o intérprete desses atos de alcance coletivo está consciente do seu poder sobre o destino do grupo, a sua consciência não pode deixar de ser trágica. Herdámos essa sabedoria da filosofia grega. O peso decisivo da decisão do mentor sobre a vida dos habitantes da cidade. Por outro lado, um dos aspetos de que eu me apercebi foi que as pessoas que uma vez na vida foram envolvidas no tumulto de uma mudança histórica, sentem dificuldade em aceitar uma existência comum como é a vida pacata que a democracia implica. Para já não falar de como se trata de um sistema em que as imperfeições se tornam bem mais visíveis do que os sucessos. As imperfeições estão sempre diante de nós, e neste caso o memorável, aquele que se sacrificou por uma alteração, vai ficar para sempre com a ideia de que a sua ação foi incompleta, de que a democracia imperfeita não faz justiça à altura do seu gesto. Muitas vezes refugiam-se na extremíssima esquerda, outros na extrema-direita, ou pura e simplesmente passam a vida a arrependerem-se do que fizeram. Foi o que aconteceu também com os principais intérpretes do Maio de 68, que tiveram muita dificuldade em aceitar a normalidade democrática da França. 
Público - Mas de entre os memoráveis da revolução portuguesa de 1974, ninguém ficou imune a esse desgaste? De tantos participantes, nenhum deles ficou marcado por um destino de exceção?

LJ - É a dinâmica da própria vida. O envolvimento com a transição democrática levou ao desgaste da imagem de muitos dos intervenientes. A exceção mais notória foi Salgueiro Maia, que em Os Memoráveis aparece com o nome de código de Charlie 8. À exceção dele, que não quis nada, não exigiu nada, não quis pertencer a nenhum partido, preferiu prolongar em si a madrugada de 25 de Abril para sempre, e cuja imparcialidade e rigor foram punidos, todos os outros foram envolvidos na onda da vida comum. De facto, no terreno, ele foi o militar que três vezes se ofereceu à morte naquela manhã. Três vezes esteve à beira de ser eliminado. Mostrou uma coragem extraordinária. Anos depois, por ironia, foi nomeado diretor da prisão dos militares, a maior humilhação que se podia fazer a um homem que tinha liderado a devolução da liberdade aos portugueses.

\section{Público - Mas porque aconteceu essa situação?}

LJ - Essa injustiça aconteceu porque as estruturas militares, a seguir ao 25 de Abril, não foram renovadas, continuaram praticamente as mesmas do tempo da ditadura. Então aquele homem deixou de ser tido como um operacional revolucionário, passou a ser um implicado num golpe de estado. A palavra implicado em português tem uma conotação muito forte. O implicado significa o insurreto. Em vez de ser o herói, passou a ser o culpado, o indiciado, aquele que merece ser julgado e punido. Os intérpretes da revolução passaram a ser os implicados no 25 de Abril. Por isso, em Portugal, há cinco anos, quando o livro foi publicado, os jovens tinham, e continuam a ter, duas narrativas opostas - uma que defende a ideia de que o desenvolvimento de Portugal não aconteceu com a profundidade esperada por causa da revolução. A revolução surgia-Ihes como um obstáculo histórico que Ihes explicava, naquele tempo da grande crise financeira que se seguiu ao crash dos bancos em 2008, como a causa remota e próxima da situação difícil que se vivia em Portugal. Muitos dos jovens passaram a reproduzir discursos retrógrados referentes a um tempo que não tinham vivido, e que lhes surgia como paradisíaco. Diziam - "No tempo de Salazar era melhor, porque havia ordem, porque havia serenidade, não havia corrupção, agora temos um estado cleptómano...". Esquecendo que antes não havia liberdade de expressão, nem de informação, nem de reunião. Desconhecia-se quanta corrupção existia. Assim, é comum, em Lisboa, falar-se com taxistas que durante um breve percurso pelas ruas, vos tentam convencer 
que a democracia é um estado de ladrões, e que Salgueiro Maia foi o responsável por ter aberto a porta a esses desmandos. Que antes do 25 de Abril é que era bom. Em tempo de crise violenta como foi a que se seguiu a 2011, esse tipo de discurso tinha grande sucesso, e continua a ter em alguns meios da sociedade portuguesa, incluindo alguns meios universitários.

\section{Público - É difícil de avaliar a dimensão desse desentendimento?}

LJ - Sim, é difícil, mas há sintomas que o tornam evidente. Felizmente que há jovens mais informados, curiosos e abertos ao entendimento dos movimentos sociais e políticos, que pensam de forma oposta. Que compreendem os valores que estão em causa. Que conhecem o episódio ocorrido no próprio dia 25 de Abril, quando Spínola, um general conservador, que defendia a manutenção de muitas das estruturas do Estado Novo, em plena revolução, ao dirigir-se ao grupo de oficiais que tinha comandado as operações revolucionárias, entre eles, Otelo Saraiva de Carvalho, lhes disse, naquele mesmo dia, alguma coisa assim: "Rapazes, fizeram um bom trabalho, vocês vão ser todos recompensados". E um dos capitães respondeu: "Não, meu general, nós não o fizemos por recompensa. Isto ainda não terminou, e se for necessário, os tanques ainda estão na rua, voltamos a fazer a revolução outra vez". Quer dizer, os capitães tinham percebido perfeitamente o que o general pretendia.

\section{NT - ... mandá-los para casa.}

LJ - Sim, mandá-los para casa para poder manter as estruturas fundamentais do Estado Novo intactas. Mas os capitães tinham combinado entre si não aceitarem recompensas, nem medalhas nem benesses, nem promoções. Tinham-no feito em nome do povo, para lhe dar a liberdade, e para se poder pôr fim à Guerra Colonial.

\section{NT - Mas foram medalhados e promovidos, muitos deles...}

LJ - Passado tempo, passado tempo. Um momento que merece estudo, um momento verdadeiramente ficcional. Porque, entretanto, figuras secundárias, comprometidas com o sistema que havia sido derrubado, começaram a ganhar relevo, ultrapassando os reais intérpretes, que entre si representavam várias áreas de pensamento e ideologias. E para dizer a verdade, por vezes os reais intérpretes também se mostraram insubmissos e individualistas, criando rivalidades entre si. Foi um período muito difícil. $\mathrm{O}$ que me atraiu para a escrita deste livro e constitui no fundo 
a sua carne, foi a ambiguidade dessas situações, a ironia da História, a erosão da memória. Por isso escrevi um livro com certo grau de complexidade, porque querendo ser fiel à História, me distanciei dela criando uma fábula que em si condensasse o conflito. Mas creio que Os Memoráveis pode ser lido em vários níveis. Um nível para quem não viveu nem conhece esse acontecimento ocorrido em Portugal, lendo-o apenas como uma narrativa, uma fábula, mas também por aqueles que se interessam pela forma como da História se passa à mitologia.

\section{NT - Fez muita pesquisa, ou sendo um período que acompanhou de perto, socorreu-se sobretudo da sua memória?}

LJ - Também fiz pesquisa. Os dados históricos surgem transfigurados, mas mesmo assim, reportando-se ao real têm de ser rigorosos. Até agora ninguém me disse ter encontrado erros. Nem sequer erros insignificantes. Isso conforta-me. A minha aposta foi escrever sobre um real transfigurado, e os dois planos tinham de se ajustar. O que não foi difícil. Havia a memória, e sobretudo a escrita que me empurrava facilmente para diante. Escrevi este livro com muito entusiasmo. Os dados da realidade, eles mesmos eram e são ficcionais. Foi só revesti-los de palavras, revisitar um mito real, e contribuir para criar um mito literário. Por exemplo, na manhã da revolução, há um episódio ocorrido na Baixa muito comovente. O momento em que Salgueiro Maia se coloca diante da torre do carro de combate das forças do governo, enfrentando a força defensiva. Era como se dissesse "Atirem se são capazes". Ora quem estava no interior do carro de combate acabou por desobedecer ao comando. O furriel que deveria fazer detonar a descarga sobre a figura de Salgueiro Maia, reconheceu-o e desobedeceu, não atirou. Talvez tenha sido esse o primeiro momento decisivo desse dia extraordinário. Essa matéria-prima é tão elevada que a efabulação se faz sem esforço, basta encontrar a forma de tornar extraordinário na página o que já tinha sido em vida. Sinto alegria quando os jovens de trinta, quarenta anos que leram Os Memoráveis me dizem "Agora eu compreendo que tenha sido importante, e quanto os dias de hoje devem a esses dias de então".

NT - No entanto, as personagens não estão identificadas, a Lídia alterou-Ihes os nomes. Precisamos de fazer um esforço para os reconhecer, como se tivesse criado adivinhas.

LJ - Creio que essa identificação com as figuras reais não seja muito importante, ainda que se tenha tornado atraente para alguns leitores descobrirem a quem corresponde cada uma das figuras. Na verdade, 
a atribuição de outros nomes aos intérpretes que são conhecidos faz parte do processo da transfiguração, da irrealidade que atravessa toda a narrativa. É uma espécie de fantasia que sustenta a parábola que está contada. Esses nomes, ao passarem do relato diarístico para o relato literário, perdem o seu sentido concreto e devem passar a ter um sentido mítico. No fundo é uma promoção daquilo que foram e/ou são para aquilo que representam. Quem participa num movimento tão forte, decisivo como é uma revolução, depois tem dificuldade em encarar a vida real com naturalidade. Porque participou em alguma coisa de transcendente, sente-se deslocado no meio da vida comum. Alguém que viu armas apontadas ao peito, que enfrentou a morte, que disse palavras fundamentais para o futuro de toda a nação, como pode depois levantar-se todos os dias, tomar banho, atar as botas, vestir-se normalmente e ir para um emprego comum? Não consegue. Tem dificuldade. El Campeador, a personagem que representa Otelo Saraiva de Carvalho, o verdadeiro estratega da revolução, acabou até por ser preso. $\mathrm{Na}$ realidade, trata-se de uma personalidade maravilhosa, e ao mesmo tempo contraditória, uma verdadeira figura de ficção. Não poderia nesta fábula chamar-se Otelo, teria de ser nomeado como uma figura ao mesmo tempo grandiosa e teatral. Em Os Memoráveis, tem nome de canção de gesta, El Campeador, como El Mio Cid. É nessa condição, de figura mítica da Idade Média, sonhadora e teatral, que ele é entrevistado pelos três jovens jornalistas, enquanto galopava à beira das ondas da Praia Grande.

\section{NT - Pode falar-nos das perguntas que os jovens jornalistas lhe dirigem?}

LJ - Há umas célebres entrevistas, conduzidas por Baptista Bastos, que sempre começavam pela pergunta "Onde é que você estava no 25 de Abril?". As respostas eram naturalmente muito diferentes, as interpretações sobre o sentido desse dia, também. A cada um a sua ideia. Este livro foi escrito há cinco anos, mas a ação localiza-se em 2004 e a pergunta foi outra: "A esta distância no tempo, o que pensa sobre a sua própria ação? E qual é o balanço que faz sobre o 25 de Abril?". As perguntas que os jovens jornalistas colocam aos militares são uma espécie de réplica dessa mesma questão, para que cada um deles pudesse fazer um balanço da sua própria contribuição para esse movimento, e mostrar como interpretava o sentido do tempo decorrido desde então. É assim que El Campeador, a si mesmo se considera a figura que fora a mais importante, tomando-se pelo verdadeiro "Herói do Mar". Salamida, o rapaz responsável por ter colocado no ar a canção Grândola Vila Morena, a senha do 25 de Abril, aos microfones da Rádio Renascença, responde que o que fez, entretanto, foi usurpado por outros, tendo-Ihe desfeito a reputação, e ao mesmo tempo 
vive a pensar num trecho musical para marcar o início de uma revolução necessária no futuro, em face da deriva e deterioração no interior do estado democrático. No caso de Charlie 8, entretanto desaparecido, é a sua viúva quem responde às perguntas dos jovens jornalistas. Mas não Ihes diz a verdade, receia que se falar do ressentimento que a acompanha pela injustiça de que o marido foi alvo, a vingança por ter sido a figura determinante da revolução, ainda mais se acentue, fazendo apagar o que resta, o elogio da sua memória.

\section{NT - Quais foram as reações que o romance provocou?}

LJ - Posso dizer que foi muito bem aceite. Teve opositores: muitos dos que idealizaram a revolução de abril e que se recusam a mencionar as falhas, os problemas que vieram a seguir, acham que se trata de um livro antiabrilista. Isso acontece porque leram de forma imperfeita o livro, creio eu, ou thes passaram mensagens erradas sobre o livro e não leram sequer. E há leitores conservadores, alguns de extrema-direita, que acham pelo contrário, que eu voltei a um tema já passado, o tema da revolução, e que já estão fartos de ouvir falar do assunto. Para esses, tomara que não tivesse havido revolução nenhuma, mesmo tendo sido beneficiários dela. Os Memoráveis, para esses leitores, não passa de um incómodo. Mas de um modo geral, foi bem recebido, muito lido em face dos parâmetros de leitura atuais. Suscitou diálogo, controvérsia, leitura de trechos em vários fóruns, criou sentimentos de reconciliação, avivou memórias e creio que desencadeou alegria.

NT - Mas continuam a surgir críticas na imprensa, nomeadamente contra Otelo, por causa das FP25... ${ }^{1}$

LJ - Essa situação com Otelo continua a ser um capítulo por encerrar. Constituiu um excesso, o lado transbordante de um movimento que não admitia o jogo plural da democracia. Aconteceu em muitos países. Mas esse aspeto não invalida o papel decisivo que Otelo desempenhou. A questão é que a revolução portuguesa continua a ter detratores e defensores enquanto movimento pioneiro na história da democratização das sociedades no último quartel do século XX, uma realidade que desde há alguns anos se tem vindo

\footnotetext{
1 As Forças Populares 25 de Abril (FP25) foram uma organização armada clandestina, de extrema-esquerda, ativa entre 1980 e 1987, que lutava contra a evolução política que o país tomou após o 25 de novembro de 1975 (reação a uma tentativa de golpe militar de uma fação das forças armadas) que acabou com o PREC (Processo Revolucionário em Curso). A chamada normalização política do país não agradou aos setores mais radicais da esquerda que se organizaram nesta organização armada. Levaram a cabo vários atentados bombistas, a tiro e roubos a bancos, viaturas de transportes de valores, etc. Parte dos seus membros foram levados a julgamento, apesar da dificuldade de os encontrar e de encontrar provas dos seus atos.

A personalidade mais conhecida desse movimento foi Otelo Saraiva de Carvalho, capitão do Movimento das Forças Armadas que planeou a revolução. Otelo Saraiva de Carvalho foi o responsável pela direção das operações do golpe de estado de 25 de abril de 1974. Teve um papel importante no pós-revolução, nomeadamente como dirigente do COPCON (Comando Operacional do Continente que tinha como objetivo fazer cumprir as diretivas saídas da revolução), foi candidato às eleições presidenciais em 1976 e em 1980 criou um partido político, a Força de Unidade Popular. Foi acusado de pertencer às FP-25, detido em 1984 e julgado em 1985. Recorreu da sentença, mas ficou em prisão preventiva 5 anos, em liberdade provisória.
} 
a viver ao contrário. Hoje em dia, assiste-se a uma antidemocratização galopante um pouco por toda a parte. É assim que o jornal Público publicou textos muito interessantes sobre a Revolução, no passado dia 25 de Abril, mas no dia 26 três colunistas apoucaram-no, minimizaram o movimento que deu a democracia a Portugal, o regime em que vivemos há mais de quarenta anos. Parece estranho, mas acontece. Há quem vasculhe os defeitos de carácter dos antigos capitães, há quem aponte as falhas dos seus percursos pessoais posteriores. Salgueiro Maia por certo que não teria hoje a imagem intocável que mantém, e que faz dele um herói dos tempos modernos, porque de certeza que, se fosse vivo, já teria interpretado algum episódio passível de o diminuir. Os Memoráveis precisa de ser lido por leitores cultos.

\section{NT - Em que sentido?}

LJ - Quem faz uma leitura superficial pode dizer o que alguns me têm dito - "Ah! Você fez do diplomata americano um herói e, portanto, você está a falsear a verdade". Mas uma pessoa sensivel aos detalhes, percebe que ao atribuir ao diplomata americano o epíteto de padrinho, isso o transforma numa figura dupla, considerada pelos portugueses como uma pessoa mafiosa. Depois vai-se aos registos, folheiam-se os documentos, cruzam-se os dados, avalia-se de longe o que se passou, e percebe-se que Frank Carlucci exerceu uma influência positiva no período que se seguiu à revolução. São as imagens fixas, deturpadas, que eu quis desconstruir.

NT - Acho que é muito interessante conhecer as forças subterrâneas que se opunham à revolução, a tal "maioria silenciosa", se quisermos compreender as ações que hoje ainda perduram, porque caso contrário não é compreensível.

LJ - As sociedades nunca constituem um todo uniforme, mesmo as que estão submetidas a regimes ditatoriais. Mas é nas sociedades livres que essa heterogeneidade mais se mostra porque existe voto democrático e liberdade de expressão. Se repararmos bem, todos os países são países divididos. Faz parte da natureza humana, faz parte da configuração dos grupos humanos. Basta olhar para a Europa dos nossos dias para se perceber como os países estão divididos. Como existe uma extrema direita em França, que nunca tinha deixado de existir, que estava lá, aguardando o momento. Existe no Reino Unido uma extrema direita nacionalista, xenófoba, que afinal estava lá, só que não se mostrava. O mesmo em Espanha. Quem imaginava que os franquistas tinham desaparecido, estava enganado. Sempre houve quem fizesse a saudação romana nas 
traseiras da casa. Estavam dispersos, mais ou menos invisíveis, mas já aí estão eles e em força. A Alemanha é um país democrático, ninguém duvida, mas existem nazis, outra vez, cada vez mais organizados e interventivos. Quem diria? Desengane-se quem pensa que em Portugal não existem franjas totalitárias à espera de ocasião. Ora o que aconteceu, a seguir ao movimento revolucionário, foi ter-se assistido a vários tipos de luta até se configurar finalmente o regime democrático. Surgiram partidos de esquerda totalitária, surgiram partidos de direita de vocação fascizante. A "maioria silenciosa", em 1975, representava um vasto grupo reacionário que, na altura, não encontrava meios de se expressar, mas existia. A sua dimensão nunca se conseguiu avaliar. Hoje em dia, os representantes desse tipo de ideário em Portugal começam a ter rosto e expressão.

NT - Para isso eu costumo dizer que, às vezes, é bom Portugal ser mal-organizado, as pessoas não terem grande capacidade de organização, e por isso não se conseguir uma divulgação tão organizada dessas ideias.

LJ - Somos um país curioso, mais do que termos falta de capacidade de organização, para o bem e para o mal vivemos no estado de vizinhança. Sufocados uns pelos outros. Eduardo Lourenço é o nosso filósofo de eleição, e claro que foi sempre muito mal olhado pelo antigo regime. Conta ele que, certa vez, vindo de comboio de Paris para Portugal, nos anos sessenta, quando ia a entrar em Portugal, surgiu um agente da polícia política para o escoltar até Lisboa, para o conduzir à sede na Rua António Maria Cardoso. Eduardo Lourenço percebeu do que se tratava e começou a falar amavelmente com o PIDE. ${ }^{2}$ Quando chegou a Lisboa foi encaminhado para a sede dos interrogatórios, para ser preso, naturalmente. Só que o PIDE, que o tinha acompanhado no percurso, trocou algumas impressões com o agente que o iria interrogar, e este, em vez de lhe fazer o interrogatório perguntou-lhe se era verdade que vivia em Paris. E sendo assim, se não poderia arranjar um emprego para um sobrinho

2 Polícia Internacional de Defesa do Estado (PIDE), polícia política portuguesa entre 1945 e 1969, mais conhecida pelo acrónimo. As suas funções abrangiam também o serviço de estrangeiros e fronteiras. Informalmente, de modo pouco preciso o acrónimo pode também referir-se à polícia política anterior (Polícia de Vigilância e de Defesa do Estado) e à que se the seguiu (Direção-Geral de Segurança), sendo por vezes designada por PIDE-DGS. 


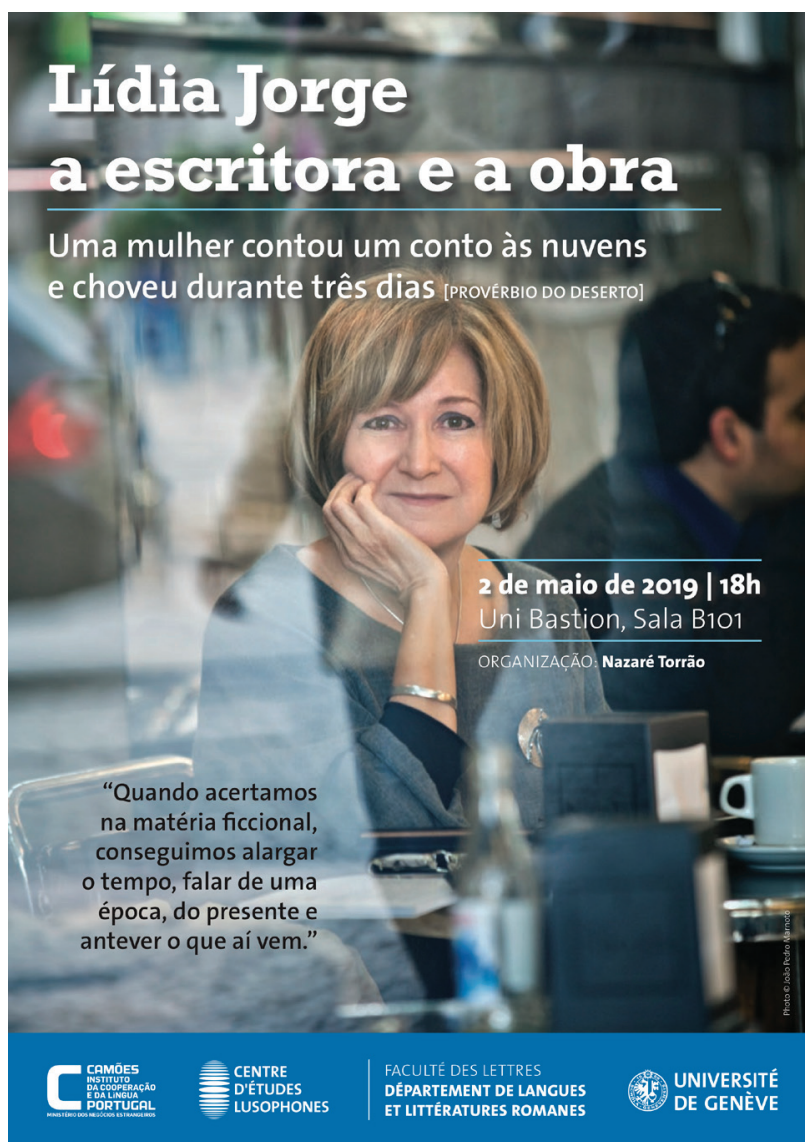

imagem 1

Cartaz do evento.

\section{NT - ... Familiarismo...}

LJ - Sim, familiarismo. Na primeira parte de Os Memoráveis conta-se que em 1975 eram enviadas cartas à personagem que representa o então embaixador dos Estados Unidos em Portugal, Frank Carlucci. Na sua maioria, eram cartas enviadas pelas pessoas que estavam contra a revolução e que lhe pediam que interviesse no processo, mas havia também pedidos de ajuda e a informação de quem eram os revolucionários que ajudavam as famílias dos agentes da PIDE. São cartas inventadas a partir de factos concretos. Os militares, mesmo Otelo que fazia parte de uma organização chamada Copcon [Comando Operacional do Continente], apiedavam-se das famílias dos PIDES. Os PIDES saíram do país e ficaram as mulheres com as crianças. Ora os revolucionários não maltrataram essas mulheres, não fuzilaram ninguém, não perseguiram quem quer que fosse, sabiam simplesmente que as pessoas estavam a passar mal, e em alguns casos mandaram-Ihes dinheiro. $O$ que é revelador de uma característica muito portuguesa. 
NT - Pois, não deve ter acontecido em mais lado nenhum...

LJ - Sim, isto não acontece em mais lado nenhum. O que dá a dimensão de como as sociedades não são ainda iguais... Ainda somos diferentes.

Público - Em relação aos militares, eles estiveram em África, enviados pelo regime de Salazar, e fizeram o 25 de Abril... Como explica isso?

LJ - Não havia uma politização dos militares. Aliás, pura e simplesmente, não havia politização nenhuma. Nessa altura, eu era aluna da Faculdade de Letras e a politização de que se dava conta era demasiado vaga, apenas tinha consciência de ser contra o regime, mas eu não sabia nada sobre política, nem tinha partido político. As nossas próprias vidas eram contraditórias. Eu era contra a guerra colonial, mas acompanhei o então meu marido, oficial da Força Aérea, no seu envolvimento com o conflito. Só em África é que as pessoas se apercebiam que havia um erro, que nós caminhávamos ao arrepio dos ventos da História. Desde os finais da Grande Guerra que a Europa tinha compreendido, embora paulatinamente, que as colónias representavam realidades contra as ideias humanitárias do século XX, as ideias políticas e filosóficas de progresso e parceria, que a relação entre os europeus e os povos que haviam sido colonizados não poderia continuar inalterável. Os militares portugueses destacados nas colónias compreenderam-no. Instaurar um regime democrático em Portugal e emancipar as colónias, parar de imediato com o conflito armado, tornaram-se faces contíguas da mesma moeda. Lutaram por esses dois objetivos e conseguiram. A revolução provocou essas mudanças todas em simultâneo. Foi bom ter assistido a isso.

Público - Havia alguma razão para que Portugal permanecesse como potência colonizadora em África, e também na Ásia, depois de todos os outros países da Europa já terem ultrapassado essa fase?

LJ - Haverá causas remotas e outras próximas. Portugal foi o primeiro país que fez a circum-navegação da África, à data, um país pequeno, com apenas três milhões de habitantes. Isso sempre fora enaltecido na antiga escola primária. Fazia parte do ideário comum dos portugueses, essa ideia de pertença mútua. De forma bastante lunática, os poderes públicos olhavam com altivez para a Europa, queriam que Portugal se mantivesse orgulhoso, descendente do ideal imperialista do século XVI. Além disso, em Portugal, a linha dura tradicional não via maneira de o país sobreviver sem a ligação económica às colónias. $E$, portanto, durante muito tempo, defendeu-se a ideia louca de que havia um Estado pluricontinental unido 
por forças espirituais. Só que isso pensavam as pessoas em Lisboa, mas quem viajava percebia que não podia ser assim, percebia que cada país teria de ser autónomo. E facilmente concluía que a ditadura exercida nas colónias era a mesma que era exercida sobre o povo português. Tanto as colónias quanto os portugueses, encontravam-se submetidos à mesma visão retrógrada. Por isso, a revolução portuguesa tem um significado tão amplo, e por isso os militares, que conheciam a experiência dolorosa da guerra em África, conheciam bem a tragédia da dor e da morte nas picadas africanas, planearam e conseguiram executar uma revolução sem sangue.

NT - Essa longa guerra de guerrilha também tinha chegado a um ponto sem retorno. Sobretudo na Guiné havia toda uma parte do território onde os militares portugueses em 1974 já não entravam...

LJ - Sim, já não entravam.

NT - Em parte, já era independente...

LJ - Em Moçambique era diferente, mas o norte do território, no início de 1974, estava completamente tomado, os independentistas encontravam-se às portas da cidade da Beira. Era uma situação insustentável. A razão encontrava-se do outro lado, uma luta armada a favor da emancipação dos povos africanos. Como não era visível para todos, à beira do último quartel do século $X X$, que não se poderia continuar a apostar na velha lógica imperialista? Depois de mais de setenta anos de denúncia da relação desumana que se estabelece entre colono e colonizado? Entre ditadores e povos submetidos ao sacrifício do extermínio? Aliás, em 1992, Sven Lindqvist desenvolveu uma tese muito interessante. Segundo o escritor sueco, o colonialismo africano teria servido de ensaio para o Holocausto europeu. O livro chama-se Exterminate All the Brutes, uma frase retirada do livro do Joseph Conrad, o primeiro grande livro literário anticolonialista.

\section{NT - O Coração das Trevas?}

LJ - Sim, publicado pela primeira vez em 1902. Esse livro tem de ser lido de duas maneiras: trata-se de um livro progressista para a época porque contra o colonialismo. Mas ainda é um livro com traços racistas. Aliás, Chinua Achebe, em 1975, em An Image of Africa, insurgiu-se contra a devoção generalizada que se mantém em torno de $O$ Coração das Trevas, como um livro libertador, quando, em sua opinião, se trata de 
uma obra que, na sua ideia, apresenta nítidos traços discriminatórios, e não deixa de ter razão. Apenas Chinua Acheve não consegue admitir o óbvio. Joseph Conrad, escritor que esteve à frente do seu tempo, apesar de tudo, também era filho do seu tempo. Todos, em parte somos fillhos do tempo passado. Também somos pais do tempo futuro. Que um dia será passado. A Literatura ensina a convivermos com essa dupla dialética.

\section{NT - E conseguimos aplicar essa lei da dupla dialética ao tempo presente?}

LJ - É muito interessante. Nós hoje temos uma ideia de humanidade bastante diferente daquela que as pessoas tinham durante o século XX. Nós hoje queremos que a humanidade toda se entenda. Percebemos que só há uma humanidade. Acho muito importante percebermos esses diferentes graus que as sociedades foram estabelecendo até chegarmos à ideia de humanidade de hoje. Convivemos com a ideia de que os seres humanos são inevitavelmente violentos, mas também conhecemos a força do idealismo que podem desenvolver, e essa dualidade evolui. Os três livros que antes mencionei falam da evolução da humanidade em momentos diferentes. É muito importante a leitura dessa evolução que culmina hoje, no século XXI, numa atitude nova. Hoje a literatura de todos os quadrantes é uma literatura global, tende a não ter fronteiras, fala de fronteiras culturais, mas não tem fronteiras antropológicas. A literatura moderna mostra que nós queremos quebrar as barreiras antropológicas, embora continuemos a braços com barreiras culturais e religiosas. Mas percebendo como se ultrapassaram as barreiras antropológicas, acho que se consegue muito melhor compreender como se quebram as barreiras culturais.

NT - No entanto começam a surgir, como disse antes, ideias de separação. $\mathrm{Na}$ Europa, com o Brexit, com todos os países de leste que não querem deixar entrar os migrantes, que constroem muros... todos os muros que se constroem de novo vão contra todos estes passos que a civilização já tinha feito e para os quais a Europa, apesar de todo o seu lado burocrático e económico também contribuiu - tinha também um certo ideal... Que agora é contrariado por todos estes muros que tendem a erguer-se de novo.

LJ - A doutora Nazaré Torrão sabe tão bem como eu, que em todos os momentos da cultura e da civilização há dois carros que avançam em sentidos opostos. Um carro que puxa para a frente e outro que puxa para trás. Ultimamente têm pedido aos escritores para que falem sobre a Europa. Mais concretamente, como é que a partir de Portugal 
se vê esta questão. Eu costumo invocar uma imagem de 1997, quando se estava a tentar retirar do solo as minas usadas nas guerras civis em África. Angola estava cheia de minas antipessoais que tiravam braços e pernas a crianças. A princesa Diana que morreria alguns meses mais tarde, foi ao Huambo, a 15 de janeiro, fazer uma campanha promovida pela Cruz Vermelha Internacional para que os países se unissem e procedessem à desminagem do terreno. A princesa foi lá, e nesse dia deixou-se fotografar com crianças decepadas ao colo. Há sobretudo uma imagem muito comovente em que ela tem um menino sem pernas nos braços. Ela junta-o ao peito e fecha os olhos e é a imagem da compaixão. Essa imagem correu mundo, a compaixão da princesa Diana para com as crianças sem pernas. Mas nos dias seguintes os jornalistas descobriram que as minas que tinham decepado aquelas crianças eram de fabrico inglês. E esta é a tragédia da Europa, é que ela desenvolve os ideais mais puros da Humanidade, conta com filósofos como Kant, Hegel, Marx, tem criado música magnífica, cantatas, oratórias, grandes sinfonias, poetas magníficos sem fim, Schiller, que escreveu o poema para a Nona Sinfonia, em que nos chama a todos irmãos, e Deus, acima de nós, olhando por todos, essa sinfonia que se transformou no hino da Europa, e afinal, ao lado de toda essa corrente interminável de idealismo, ou simplesmente de fraternidade, grassa a horda dos mercadores de todos os géneros, a lógica macabra dos negociantes que tudo subverte. Os muros de que fala são a prova dessa subversão. O carro que puxa para trás.

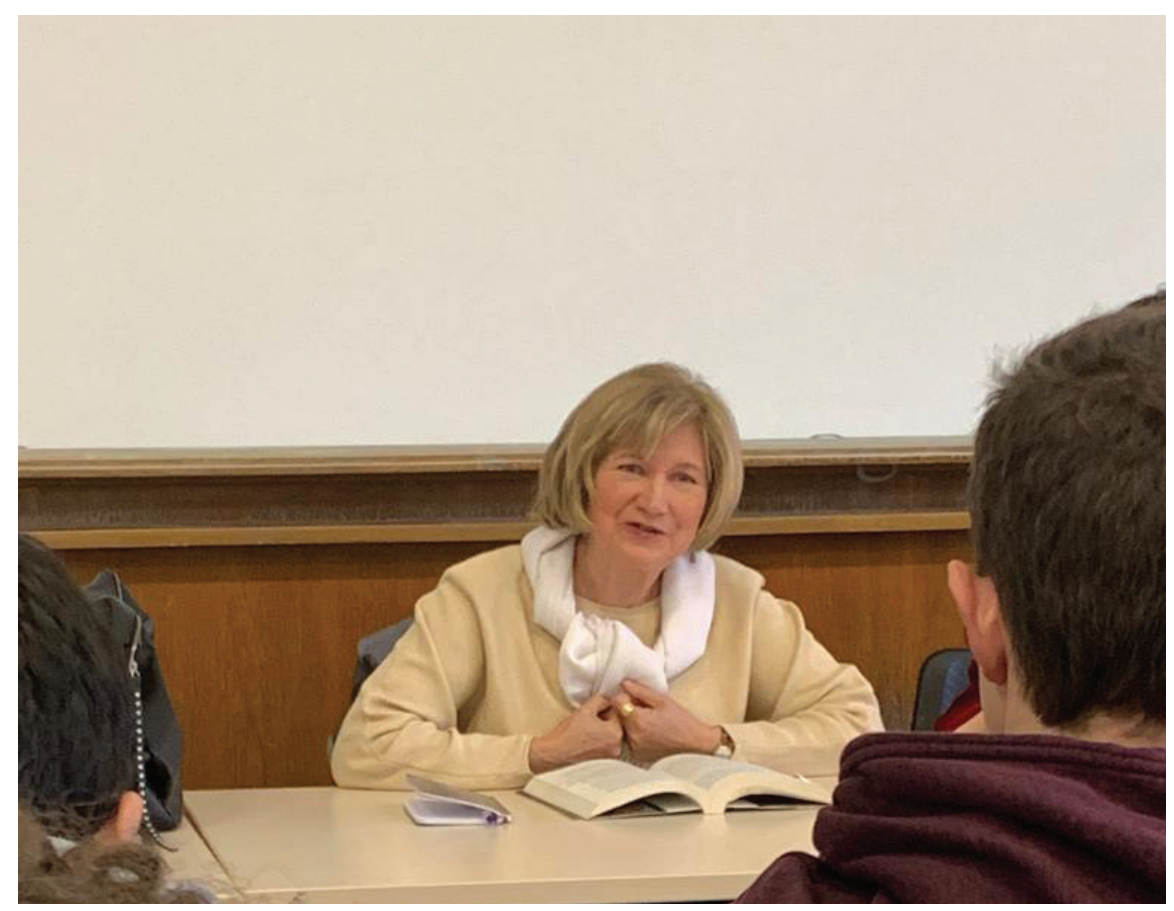

\section{imagem 2}

Lídia Jorge. 


\section{NT - E o carro da Literatura, como puxa ele para diante?}

LJ - A poesia, mãe de todos os géneros, o ensaio, o teatro, a ficção, são disciplinas, chamemos-lhe assim, dentro da grande casa da Literatura. Decompondo-a nas várias disciplinas, percebe-se melhor que se trata na globalidade, da grande arte da linguagem. E as palavras são a base no nosso entendimento primeiro e último. Desde a simples comunicação fática à transfiguração poética, a linguagem é matéria do próprio pensamento. Por isso ela está na base de todas as outras artes. Se se empobrecer a leitura da Literatura, todas as artes irão empobrecer. A arte da linguagem alimenta a base da configuração mental humana. Nesse domínio, o romance ocupa um lugar muito especial. Filho íntimo do século XIX, é o género que melhor ensaia nos leitores a capacidade de nos colocarmos no lugar do outro. A alteridade é o suporte da fraternidade. O romance é irmão gémeo da revolução industrial e dos direitos do homem. Gosto particularmente das reflexões de Milan Kundera sobre o assunto. Refere de forma brilhante como o romance ajudou a mudar a civilização e a cultura entre os séculos XIX e o XX. Um caminho que nunca está percorrido e que nunca podemos errar.

NT - Para isso é preciso continuar a investir na educação das humanidades nas universidades.

LJ - Encontro a maioria dos grandes leitores nas universidades, porque esse é o lugar que promove a contemplação dos livros como objetos de sentido múltiplo. Cultural, estético, profético. A Universidade é um lugar onde o tempo humano, felizmente, continua a ter um ritmo humano. E fazer um leitor demora muitos anos, demora pelo menos 20 anos. Aliás, um leitor de literatura precisa de saber, de ter todo um tecido de leituras feitas para compreender a proposta de cada novo livro. É uma formação que se faz por degraus, que acontece com ritmo de lentidão, não se compagina com a pressa do fetichismo tecnológico. Usa a tecnologia, utiliza-a e reutiliza-a, mas preenchendo-a de conteúdos próprios da subjetividade. Se a Universidade deixar de apostar nas Humanidades, as sociedades só terão corpo, grande corpo, mas caminharão sem cabeça, caminharão sem sentido, as sociedades serão corpos degolados.

NT - Já que falou do poder da literatura para imaginar um futuro diferente, isso faz-me pensar no seu último romance, Estuário. Para começar essa ideia de estuário relaciona-se com o de abertura ao mar. Mas ao mesmo tempo eu fiquei intrigada com esse romance... 
LJ - Eu notei...

NT - Fiquei intrigada ... esse personagem vem de um campo de refugiados, ele vem diminuído fisicamente... As pessoas e a sociedade não dão resposta a esses refugiados. Uma situação atual que todos conhecem através dos media... Há toda essa sociedade global que se está a desagregar, a personagem vem para Portugal e a sua própria família desagrega-se, mas ele tem um projeto de escrita. Todavia, ao longo de todo o livro, ele não chega a escrever. Ora, em muitas das suas obras, é através da escrita que se dá a construção pessoal do indivíduo e também a libertação, mas aqui esse projeto fica em suspenso. Pode falar-nos um pouco deste último livro?

LJ - Não gosto de condensar a história de um livro. A história é apenas o pretexto para outra coisa e essa outra coisa é que importa. Mas para um auditório que não tem acesso ao livro, como falar dele, se não desse modo? - Estuário é a história de um jovem chamado Edmundo Galeano, que passou algum tempo num campo de refugiados em África, em Dadaab, no Quénia, aquele que era considerado até há pouco tempo como o campo de refugiados mais populoso do mundo. Nesse campo encontram-se pessoas que já lá nasceram, pessoas que terão agora uns 25 anos, que não conhecem outra realidade senão aquele campo de tendas. O campo fica localizado numa zona absolutamente inóspita, onde nunca chove e quando chove a força da água arrebatada leva tudo adiante. As pessoas vivem aí numa situação de extrema precariedade, e Edmundo Galeano passou por essa vivência, fez parte de uma organização não governamental que ajuda os refugiados a sobreviverem. Tendo aí passado algum tempo, apercebeu-se que Dadaab funicionava como uma parábola para a todo o Globo. E que se a má gestão da Terra prosseguisse, um dia o mundo inteiro seria um grande Dadaab. Edmundo acabou por sofrer um acidente. Ao retirar um recém-nascido de dentro de um caixote de lixo, a tampa leva-Ihe parte da mão direita. Quando regressa a Lisboa, começa a fazer exercícios para recuperar os movimentos da mão. Um dos exercícios consistia em escrever lentamente, produzindo os movimentos necessários para desenhar letras percetíveis. Entretanto, Edmundo não só recupera os movimentos da mão como descobre o poder da jubilação da escrita. É então que ele tem a ideia de contar a experiência por que passou em Dadaab, para falar do seu pressentimento sobre o futuro, para avisar a humanidade de que a persistir nas mesmas práticas, se avançará para a derrota climática e antropológica do mundo. 


\section{NT - Estuário tem então por sujeito a Terra, o grande mundo?}

LJ - É um livro sobre a vulnerabilidade da Terra, mas é também um livro sobre a vulnerabilidade de uma família, e particularmente de um jovem, Edmundo Galeano. Edmundo está de tal maneira envolvido com esse projeto pessoal gigantesco - escrever para salvar o mundo - que não consegue perceber que a sua família se encontra em desagregação e a caminho da ruína. O pai chega mesmo a cometer suicídio e ele não se apercebe da tragédia da família em crise. Só no final, quando tudo está esboroado, quando os irmãos estão perdendo os seus meios de vida, e voltando para a casa de família, é que ele percebe finalmente que só pode compreender o que se passa no grande mundo se primeiro tiver passado pela experiência do sofrimento dos que lhe são próximos. E essa é a sua experiência decisiva. Depois poderá concluir que tudo o que experimentou serve de matéria-prima, só então podendo começar a escrever sobre o que pretende. E, assim, Estuário, o livro de Edmundo Galeano, não fala daquilo que ele irá escrever, mas da aprendizagem que fez enquanto se preparava para tal.

NT - Mudando de tema, li recentemente, no jornal Le Temps [diário suíço], que as mulheres escritoras são sempre menos citadas e menos comentadas e que, por exemplo no jornal New Yorker, $80 \%$ das crónicas literárias são escritas por homens sobre homens. Gostaria que comentasse e de saber qual é a sua experiência neste domínio. Acha que as mulheres escritoras são propositadamente menos citadas?

LJ - Eu acho que não é propositadamente...

NT - Não? Mas acontece...

LJ - Acontece, acontece verdadeiramente... Talvez a experiência mais curiosa, nesse sentido, que tive até agora tenha ocorrido em Lima, no Peru. Tratava-se de um congresso de escrita de mulheres, escrita feminina, portanto, havia mulheres de toda a parte do mundo e era um grande congresso de mais de três dias, a que assisti do princípio ao fim, e para meu grande espanto, as mulheres, quando faziam citações, nunca recorriam a autoras, mas sempre, sem exceção, a autores homens. E até poderiam citar uma, não é? Tinham à mão Gabriela Mistral, a autora que escreveu "Que sejas tu aquele que tira a pedra do caminho". Eu só falei no último dia do colóquio, fui testemunha paciente, e disse exatamente isso, que as próprias mulheres não acreditavam na voz das mulheres. Ora se as mulheres não acreditam nelas mesmas, então quem acreditará? 
Essa inscrição na paternidade cultural masculina acontece por força da herança. Está enraizado o conceito de que as palavras das mulheres são menores e as mulheres, elas próprias participam nessa menorização, até que a realidade mude.

\section{NT - E estarão mesmo a mudar? A mudança não será só de superfície?}

LJ - Acho que estão mudando de facto. Muitas vezes à custa de um certo folclore que parece exagerado, mas há realidades que estão mudando mesmo. Dou o exemplo de Maria Teresa Horta, uma poeta portuguesa, feminista, que tem sido mal tratada ao longo dos anos e que hoje é reconhecida e admirada. Quando publicou, no princípio dos anos 70, Ambas as mãos sobre o corpo, o grande crítico da altura, João Gaspar Simões, escreveu alguma coisa assim - Quando Maria Teresa Horta tira as mãos de cima do seu livro, só fica o corpo. Hoje, passado este tempo, percebemos que ela foi íntegra, escreveu sobre aquilo em que acreditou e hoje as pessoas estão reconhecendo Maria Teresa Horta como talvez a mais ativa das três Marias, as três autoras que escreveram as Novas Cartas Portuguesas. Mas é muito desgastante mantermo-nos neste discurso. Por mais solto e liberal que seja, sempre se confunde com ressentimento. Não se pode, porém não dizer a verdade, a bitola para as mulheres é muito estreita. Um escritor americano menor, ao pé de uma grande escritora europeia, é ele, o escritor americano, que tem todos os louvores e a europeia é completamente esquecida. Conforta-me pensar que esta situação será passageira. Nós somos seres históricos, a história é lenta, demora e tem recuos. Penso que é preferível as escritoras lutarem pela melhoria cívica das mulheres globalmente, para que elas tenham a possibilidade de ter uma vida decente, não terem três vidas ao mesmo tempo, não serem só elas quem cria as crianças, não serem só elas a sustentar as pessoas da família... Prefiro defender as mulheres de um ponto de vista cívico, e não misturar o plano da criatividade com o plano da condição social. No estrito plano da escrita, eu considero que se trata de uma realidade de natureza andrógina. Aliás, cada vez mais se pensa assim, deixando a contenda para o plano da reivindicação objetiva.

\section{NT - Considera, então, que tem havido uma mudança de perspetiva?}

LJ - Considero, sim. Quando comecei a publicar, no início dos anos 80, setenta e cinco por cento das perguntas que me colocavam tinham a ver com o assunto - "Você é uma escritora feminina?", "Considera-se uma escritora feminista?", "A sua escrita é de quem escreve como mulher?", "Você escreve com o seu corpo de mulher?". As perguntas eram assim, 
redundantes, persistentes. Eu dizia sempre que felizmente só tinha um corpo, e era de mulher, mas o meu espírito era feito de muitos espíritos. Certo dia, resolvi fazer uma experiência. Levei para uma sessão durante a qual, por certo, a pergunta iria surgir, um texto da Agustina Bessa-Luís e um texto de Virgílio Ferreira. Li os dois textos, omitindo a autoria. Pedi que indicassem o género dos autores. Toda a gente, e era muita a que se encontrava no anfiteatro, disse que o texto da Agustina tinha sido escrito por um homem, e o do texto do Virgílio Ferreira, por uma mulher. Porque este refletia sobre o destino humano, discorria filosoficamente, projetava uma voz íntima e falava da fragilidade do ser, e o da Agustina representava a voz masculina do poder, a luta pela supremacia, a voz era de alguém que vence, ou que quer vencer. $O$ erro rotundo refletia a força do preconceito e das ideias feitas. É um lugar comum associar-se a escrita virulenta com o masculino, e a escrita suave e intimista com o feminino, e isso não é assim tão simples. Um dos meus livros preferidos é Orlando, de Virginia Woolf, em que o personagem começa como homem, atravessa uns séculos como homem, mas há um dia em que cai do cavalo, levanta-se e é uma mulher. Transformou-se numa mulher. E, portanto, tem as duas experiências, a do masculino e do feminino, e pode denunciar de um lado e do outro o que são os tabus e as ideias feitas. Porque digo que a escrita é eminentemente andrógena? Porque a invenção permite que sejamos homens, mulheres, seres mais ou menos sexuados ou assexuados. Em Estuário fui várias vezes homem, fui também mulher, fui pessoas dececionadas, pessoas ilusionadas, casa, rio e paisagem. Estuário, fui várias vezes estuário. A grande vantagem da ficção é que somos tudo em todos os seres, passamos pelos vários aspetos da humanidade, não ficamos aprisionados dentro de uma só identidade. Em suma, a questão do feminismo é importante porque promove o estatuto cívico das mulheres. A questão do género na escrita é apenas um exercício. Interessante, e com conclusões úteis, mas exercício.

NT - Falando agora concretamente de escrita em português. A língua portuguesa é muitas vezes considerada barroca, é muito flexível, permite construções que outras línguas românicas não permitem, mais claras e racionais como o francês, por exemplo. Cada um que teve a experiência de traduzir do português para o francês, lembra-se de ouvir sempre um francófono a dizer "mas isso não se pode dizer assim...". António Quadros diz que é visceralmente barroca, exprime o sinuoso, espiralada, espontânea, dinâmica, imprevisível, criacionista por natureza. Como é escrever numa língua assim? Pensa-se de uma forma diferente dos outros povos por usarmos esta língua barroca que se diz também que é menos propensa para a filosofia? E isso tem 
repercussões na identidade e na forma de agir das pessoas? São muitas perguntas numa só? Tem todo o direito a uma longa, a uma longuíssima resposta.

LJ - Vou responder brevemente. É assim, a nossa língua de facto é particular, mas eu não tenho experiência de escrever noutras línguas a não ser ocasionalmente. Quando acontece, julgo que estou sem querer a fazer uma tradução. De resto, escrevo em português e sinto-me bem, sinto-me à vontade. A língua portuguesa tem todos os instrumentos para conseguir expressar o que desejo. Sinto-a como um vestido amplo. Embrulha perfeitamente os meus pensamentos.

NT - Não acredito que nunca tenha pensando na especificidade da língua portuguesa. Já encontrei algumas opiniões suas sobre o assunto.

LJ - Cada língua tem o seu corpo e o seu espírito. Por exemplo, entre a língua espanhola e a portuguesa é grande a coincidência semântica, sintática e morfológica, mas na fonética e na expressividade verbal são duas línguas muito distintas. Cervantes disse que a língua portuguesa era o espanhol sem ossos [risos] "Español sin huesos", certamente porque considerada uma língua modelada, de textura suave. E essa síntese é muito interessante, não é? É que o castelhano avança para o final das frases galopando, como um cavalinho. $O$ cavalinho da língua espanhola trota, avança triunfante por entre as frases, e o português ondula, como se os seus ossos fossem feitos de água. Eu acho muito curiosa essa expressão do Cervantes. Com o francês a comparação é outra. Línguas mais afastadas entre si, dentro do espectro das línguas românicas, a língua francesa tem jardins de Versailles dentro dela. É geometria, racionalidade, compostura, altivez grave, feita de pompas triangulares. Basta pronunciar Allons, enfants de la patrie... para se sentir essa esquadria dentro da qual existe um camponês que tem alma de Rei-Sol. Mesmo falando de vacas e centeio, o francês é falado a partir de um palácio. O português é marítimo, e é rural do campo e da igreja de granito ou de cal, não tem palácio na sua estrutura, tem palheiro e flores silvestres. Heróis do mar, nobre povo, nação valente e imortal? Boas intenções. A língua portuguesa não acredita na nobreza nem na valentia. Acredita só na terceira categoria, na imortalidade. É uma língua feita para cantar Vem saber se o mar terá razão / Vem cá ver bailar meu coração. Estamos a falar das línguas latinas, que têm menos vocábulos do que a língua inglesa. Agora vamos pensar no inglês e no português. Este livro em inglês teria menos um quarto das páginas. Porquê? Porque o inglês tem mais vocábulos que o português, bastantes mais. O português, para 
as mesmas ideias, precisa de encontrar metáforas. A metáfora exige muitas palavras e, portanto, o texto fica longo. Mais longo em português do que em espanhol. O espanhol tem mais palavras do que o português. Para sermos francos, a língua portuguesa é maravilhosa, mas nós não podemos mentir sobre o número de vocábulos. Nós temos menos vocábulos do que os espanhóis, menos vocábulos que os franceses, menos vocábulos que os ingleses. Mas, em compensação, temos uma grande agilidade na criação de expressões. E, nesse campo, ninguém nos bate, a língua portuguesa é mais criativa do que a língua francesa e a inglesa, porque estamos treinados para a metáfora e, por isso, o português é eminentemente poético e transfigurador. Esse é o segredo da nossa riqueza expressiva. Por outro lado, este tipo de linguagem faz com que a nossa escrita seja litúrgica e repetitiva. Os textos dos portugueses, dos melhores escritores portugueses, são textos repetitivos. Vejam, por exemplo, José Saramago. Agustina Bessa-Luís repete, repete; Lobo Antunes, repete, repete... Quer dizer, há construções que parecem orações. Há alguma coisa tautológica, o vício do emparelhamento, como nos textos religiosos. A nossa poética é não só metafórica como é repetitiva, como a construção dos nossos livros, que são repetitivos. Alguns deles deliciosamente repetitivos - Eis uma resposta longa.

\section{NT - E isso continua assim com a nova geração de escritores?}

LJ - É muito interessante perceber como na nova geração há diferenças: alguns escritores mais jovens perseguem este modelo tradicional da língua portuguesa - repetitiva, metafórica, litúrgica - e há aqueles que não estão tão apegados a este conceito e que escrevem a partir de qualquer sítio do mundo e num registo de linguagem que se aproxima da tradução, uma escrita que parece não ter sítio de origem, não ter raiz. Alguns prolongam mais a herança portuguesa e outros são escritores de matriz mais cosmopolita, querem desembaraçar-se da tralha portuguesa. Eu prefiro os da tralha. Continuo a preferir os escritores que trabalham a língua do seu país e que o fazem não como adorno, mas como um conteúdo que valoriza os outros conteúdos. E o mesmo que sinto pelos portugueses, sinto, por exemplo, pelos franceses, de quem eu estou próxima, ou pelos ingleses, por aqueles que estão mais próximos da matriz original da sua língua e dos seus conceitos, porque os outros escrevem como os americanos mais populares escrevem. Livros que, mais do que livros, são guiões para filmes. Prefiro os escritores de matriz europeia, a escrita que continua a fazer passar uma metáfora e um pensamento. Isto é muito importante e é o que tenho a dizer sobre a questão da língua. 
NT - Para terminar uma última pergunta: disse que vai brevemente publicar um livro de poesia. Qual é a diferença essencial, hoje em dia, entre escrever poesia e narrativa. Ainda há essa diferença de género?

LJ - Há, ainda há.

\section{NT - Como é que é?}

LJ - Há 100 anos que é hábito dizer que não há, e eu lembro-me sempre da história antiga do Bourgeois Gentilhomme, aquele senhor que dizia "ni prose ni vers" que estava muito admirado porque tinha descoberto que afinal durante toda a vida havia falado em prosa. Ele não sabia! Regressando à sua questão, de facto, o que acontece, é que há uma diferença, mas a diferença não é estanque. O que é no fundo literatura? É linguagem comovida, isso é que distingue a literatura dos outros tipos de linguagem, da linguagem jurídica, da linguagem jornalística, da linguagem histórica, da linguagem das ciências, é aquilo que da literatura é linguagem comovida. Mas há vários graus de comoção e eu diria que a poesia reúne em abreviado o grau mais elevado da comoção. Aquilo que faz por exemplo o Carlos Carranca dizer: "toquem todos os sinos das aldeias/ o poema aconteceu nas minhas veias". São duas frasezinhas, mas têm uma elevação incomum, é o máximo da intensidade para o mínimo da extensão. O máximo da condensação semântica. O refinamento da linguagem comovida. Mas a comoção tem vários graus. O conto, por exemplo, aproxima-se da poesia porque apresenta uma grande exigência de condensação. Um conto é bom quando tem uma forte marca poética, tem um enigma que muitas vezes não se descobre, mas incita o leitor a ficar com uma imagem persistente que o desafia. É, portanto, um outro grau de condensação da linguagem, e depois o romance que em princípio é mais distendido nessa intensidade. Há páginas de romance que são poéticas. Num livro que tem por título A Costa dos Murmúrios, a certa altura há uma personagem que escreve um poema sobre a luta entre a África e a Europa, e eu considero que aquele é um momento chave do livro. O que significa que há diferenças narrativas, mas são diferenças de grau e intensidade e não de natureza. Vou publicar um livro de poesia. Espero que seja linguagem comovida.

Público - A Lídia Jorge tem uma mensagem para estes jovens, para incentivar a leitura? A leitura está em crise...

LJ - Só posso dizer uma banalidade - aquele que lê é leitor. Mas o grande leitor deveria trazer uma medalha ao peito. Que não se visse, claro, 
mas que se sentisse. Imaginem como seria, encontramo-nos na rua e reconhecermo-nos como grupo. Este é leitor, pertence ao meu género de pessoa, aquele também, e também. Formaríamos uma seita, a seita dos leitores. Seria lindo. Os membros da seita dos leitores poderiam não ter automóveis de grande potência, nem mansões, nem piscinas à porta de casa, nem férias nas Bahamas. Mas tínhamos livros, sobretudo leituras, e por isso, quando nos encontrássemos nas ruas, se fôssemos dez, à nossa volta sentar-se-iam cem vultos. As personagens que os leitores trazem consigo. E talvez, também, os autores que os inventaram. Cem viagens, cem ilhas, cem conceitos, em torno de cada mesa. Uma multidão de pessoas que vão e vêm, existem sem incomodar, à volta dos leitores. Tudo isso invisível para os não leitores, tudo isso visível só para nós, os leitores. E eu acredito, que cada um dos leitores traria consigo milhares de palavras e de novas combinações entre si. Ao sentarmo-nos em grupo, formaríamos um dicionário sem limites. Só de pensar nessa realidade me sinto orgulhosa, e apetece-me falar por cima do ombro, e caminhar direita pela rua, dirigindo-me à Criação inteira com soberba. Nós, os do clube dos leitores, nós, seremos criaturas criadoras. Só nós, a começar pelos que estamos aqui. Grande clube. 